\title{
Protests as terror law targets foreigners at universities
}

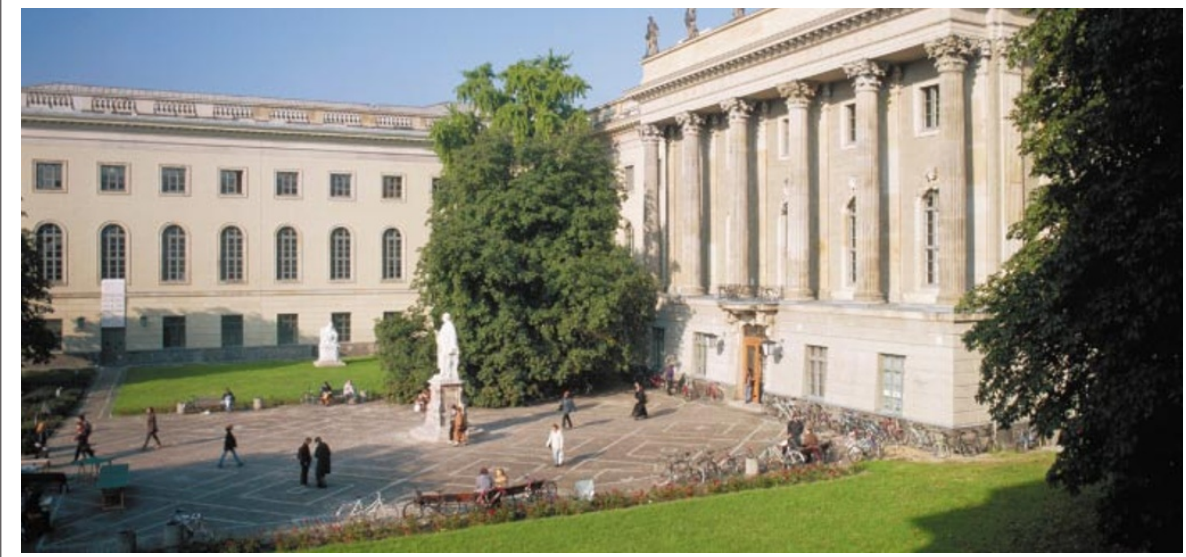

Under a shadow: Humboldt University has been forced to supply data on foreign students to the police.

Philipp Weis and Quirin Schiermeier, Munich

Germany's student leaders and academic organizations are protesting against new anti-terrorism measures that require the country's universities to give the police information about students. They fear that the legislation will increase intolerance towards foreign students and scientists, exacerbating an already worrying problem.

The new law, introduced earlier this month, allows the police to ask universities for information on male students. The information can then be cross-checked against records from other sources, including government offices, banks, airlines, car rental companies, and the authorities that issue drivers' and pilots' licences.

Universities in the state of North RhineWestphalia were asked last week to supply information on 10,000 students, including their religion, place of birth and details of when they started and ended their studies. Universities in other states have also been asked to search their files.

The measures are intended to help identify 'sleepers' - terrorists who are living in Germany while awaiting an order to attack. At least three of those involved in the 11 September attacks on America had lived in Germany before entering the United States. Mohammed Atta, who piloted one of the planes that crashed into the World Trade Center, was registered as a student at the Technical University of Hamburg.

Student organizations in Berlin and Aachen have reacted by urging university heads not to comply with the law. Most universities have, however, grudgingly accepted it. The Humboldt University in Berlin is challenging the measures in court, but has already supplied the information about its students. The university intends to ask for more control over how it handles personal data, such as the right to inform students before giving their data to the police. Although students from European countries are also covered, most of the requests concern those from Arab nations. "It is discriminating to treat Islamic students as suspects wholesale," says Oumarou Roufaou, an informatics student from Cameroon, who represents foreign students at the Technical University of Aachen. Some 4,500 foreign science students, including many from Arab countries, are enrolled at the university.

Roufaou says that Islamic students are well integrated in campus and elsewhere, but that the legislation is making them feel intimidated. "Some have already experienced distrust or hostility, for example when looking for a flat," he says. "They are avoiding the public." Indeed, Islamic student groups declined to be interviewed for this article.

German academic organizations share the unease. "The measures are excessive and badly considered. They will hardly help track down terrorists," says Rüdiger Jütte, who is responsible for foreigners' affairs at the German Conference of University Rectors.

Manfred Osten, secretary-general of the Alexander von Humboldt Foundation, which awards grants to foreign scholars, fears the measures will increase intolerance at a time when foreign scientists in Germany are worried by increasing xenophobia and right-wing extremism, and have suffered violent attacks (see Nature 406, 553; 2000).

But Uwe Thomas, state secretary for education in the federal research ministry, defends the measures. "It is in the interests of all students and scientists to make sure that no terrorists are being harboured in German institutes," he says, adding that the measures are not an attempt to clamp down on scientific exchange with Islamic countries. "We are strongly interested in strengthening scientific links with the Middle East, Iran and Pakistan," he says.
Election result leaves Australian scientists fearful over funding

Peter Pockley, Sydney

Australian voters' re-election of the coalition of right-wing parties headed by Prime Minister John Howard has dashed hopes that the election might boost the country's research budgets.

Since the vote, Howard has appointed a new science minister and has shuffled certain responsibilities between departments. But it seems unlikely that he will sanction additional money for research.

Kim Beazley, the leader of the opposition Labor Party, had been campaigning on a 'Knowledge Nation' policy, promising to double spending on research (see Nature 414, 137; 2001). But Howard's emphasis on his leadership abilities, together with his hard-line policies on asylum-seekers, proved more attractive to voters.

During the campaign, Howard had ridiculed Beazley's policy, and commentators say Howard is unlikely to revise his opinions in favour of research.

Some Australian universities are facing severe financial difficulties, but the new minister for education and science, Brendan Nelson, who took office on 26 November, has not been given the funds to remedy the situation.

University and science leaders nonetheless welcomed the departure of Nelson's predecessor, David Kemp, who frequently clashed with the education sector.

Nelson, a former medical practitioner, honed his political negotiating skills as president of the Australian Medical Association, and has appeared to be sympathetic to the cause of research since entering parliament.

He is being assisted by a junior minister for science, Peter McGauran, who has returned to a role from which he was forced to resign four years ago over irregularities in his claims for travel costs.

Howard has also surprised many observers by moving responsibility for science and the research agencies, notably the Commonwealth Scientific and Industrial Research Organisation, from the industry portfolio to that of education.

This move has puzzled science organizations because Howard, together with the former industry minister Nick Minchin, had been pushing for research to become more commercially oriented. 